\title{
MOVING BEYOND ARBITRARINESS: THE LEGAL PERSONHOOD AND DIGNITY OF NON-HUMAN ANIMALS
}

\author{
DAVID BILCHITZ*
}

\begin{abstract}
This article considers the legal personhood and dignity of non-human animals. It first argues that the concept of legal personhood can embrace all those who are capable of having rights or duties. Since the concept includes those who are rights-bearers, without necessarily being duty-bearers, it is necessary to investigate whether it is possible for animals to be rightsbearers within our law. It is argued that the traditional classification of animals as legal objects has already been challenged by the enactment of animal welfare legislation. Certain traditional justifications for such legislation cannot withstand scrutiny and it is shown that such legislation rests upon the recognition that animals have important interests in their own lives and so require legal protections in their own right. This provides the basis for recognising that they have certain rights within the law, and consequently, if we take the argument to its logical conclusion that they are natural persons rather than things. This conclusion can be reached through courts simply drawing out the implications of the existing legal regime in relation to animals. An alternative basis for restricting the category of legal personhood only to those who are members of the human species is often rooted in the notion that human beings have a special 'worth' or 'dignity' not possessed by other animals. The dignity claim is shown to be capable of two different interpretations: one that asserts the special value of human beings as a category and the other that asserts the special value of certain complex characteristics - such as rational agency - largely found only within the human species. Both interpretations are shown to be flawed and, ultimately, provide no acceptable justification for recognising that only human beings are capable of having rights that must be respected. The notion of dignity, it is argued, can be developed to remove the arbitrary exclusion of nonhuman animals. The concept, as developed recently by Martha Nussbaum, embraces all those who have the capacity to flourish and can recognise the variable nature of the good for diverse beings. The adoption of the revised conception of dignity paves the way for the recognition of the legal personhood of animals. The final part of this article considers the possibilities for interpreting both the common law and constitutional provisions so as to recognise the dignity and personhood of animals. A key problem that is addressed is whether South African society is ready to embrace the full implications of this recognition. The legal concept of 'progressive realisation' of animal rights is proposed as offering the possibility of ensuring greater protections for animals through recognising their dignity and personhood whilst embracing a gradualist approach towards the full realisation of their rights, thus preventing a wholesale disjunction between the law and the attitudes of wider South African society.
\end{abstract}

\section{INTRODUCTION}

The Animals of the world exist for their own reasons. They were not made for humans any more than black people were made for white, or women for men.'

* Director, South African Institute for Advanced Constitutional, Public, Human Rights and International Law; and Senior Research Associate, Centre for Human Rights, University of Pretoria.

1 Alice Walker quoted in M Spiegel The Dreaded Comparison: Human and Animal Slavery (1988) 7. 
The new constitutional dispensation in South Africa has famously been described by Etienne Mureinik as transforming the legal order from a culture where authority is to be respected for its own sake, to a 'culture of justification', where the exercise of power is not arbitrary and is capable of justification. ${ }^{2}$ This characterisation has found favour with the Constitutional Court on several occasions $^{3}$ and it has recently been stated in the Merafong case that ' $[t]$ he exercise of public power has to be rational. In a constitutional state arbitrariness or the exercise of public power on the basis of naked preferences cannot pass muster'. A related and central principle of the new constitutional order is that the interests of the most vulnerable in our society must be protected. ${ }^{5}$ In one of the first cases before the Constitutional Court, Judge President Chaskalson made a striking pronouncement: 'it is only if there is a willingness to protect the worst and the weakest amongst us, that all of us can be secure that our own rights will be protected'.

The move from an order where arbitrary distinctions reigned supreme and where authority and power were respected for their own sake requires lawyers to evaluate and reshape some of the basic concepts and categories of the law. Unfortunately, in the move to a new order, at times, certain of the old unjustifiable assumptions are once again replicated and it is necessary for those committed to the constitutional project to expose where this has occurred.

In this article, I argue that unfortunately the unjustifiable attitude of the old South African legal order towards animals ${ }^{7}$ has been replicated in the new dispensation. This will be explored through considering two important concepts in the law: the first is the concept of the person and the second the concept of human dignity. The first part of this article considers the concept of the person in South African law and shows how the contours of the concept have been arbitrarily restricted to include only members of the human species. I begin by considering an ambiguity in the traditional meaning of the concept of the person. If this concept is to embrace all humans, it must be capable of embracing those who are capable of having either legal rights or duties (though not necessarily both). If the concept includes those who are rights-bearers, without being duty-bearers, the question arises whether the resultant extension of the concept allows for the inclusion of non-human

2 E Mureinik 'A Bridge to Where? Introducing the Interim Bill of Rights' (1994) 10 SAJHR 31.

3 See Prinsloo v Van Der Linde 1997 (3) SA 1012 (CC) para 25; S v Makwanyane 1995 (3) SA 391 (CC) para 156.

4 Per Justice van der Westhuizen in Merafong Demarcation Forum v President of the Republic of South Africa 2008(5) SA 171 (CC) para 62.

5 This is a theme of the Constitutional Court's jurisprudence in a number of areas. For instance, in relation to equality, the vulnerability of a particular group is an important factor determining whether or not unfair discrimination may be said to be present: see, for instance, Khosa v Minister of Social Development 2004 (6) SA 505 (CC) paras 71-4.

$6 \quad$ S v Makwaynane 1995 (3) SA 391 (CC).

7 Since human beings are also animals, strictly speaking I should use the term non-human animals to refer to all members of the animal kingdom who are not members of the human species. However, to avoid the unwieldiness of this locution in every context, I generally use the term 'animal' to denote non-human animals in this article. 
animals. Traditionally, in our law, animals have been classified as things without having any rights. At the same time, however, statutory restrictions have been placed on the cruel treatment of animals. I shall consider various justifications for these statutory restrictions and argue that they cannot adequately be explained without recognising that animals have fundamental interests in their own right that deserve legal protection. That recognition in turn provides the grounding for the notion that animals may have legal rights and consequently may be recognised as legal persons. The argument here seeks to show that this conclusion can be reached merely through consistently drawing out the assumptions underlying the existing statutory legal framework governing animals.

The second part of this article then goes on to consider an alternative basis for restricting the category of legal personhood only to those who are members of the human species which is rooted in the notion that human beings have a special 'worth' or 'dignity' not possessed by other animals. The dignity claim is shown to be capable of two different interpretations: one that asserts the special value of human beings as a category and the other that asserts the special value of certain complex characteristics largely found only within the human species. I argue that both interpretations are flawed and, ultimately, provide no acceptable justification for recognising that worth only resides in human beings and, consequently, that only human beings are capable of having rights that must be respected.

The third part of this article begins with the recognition that the anthropocentric view of dignity is unjustifiable and turns to consider whether the notion of dignity can be developed in such a way as to remove the arbitrary exclusion of animals. It is argued that the concept as developed recently by Martha Nussbaum embraces all those who have the capacity to flourish and can recognise the variable nature of the good for diverse beings. This concept it is argued provides the basis for recognising worth in a wide range of sentient creatures and, consequently, for requiring that the fundamental interests of such creatures be protected through fundamental rights.

I then draw out the implications of this revised conception of dignity and argue that it paves the way for recognition of the legal personhood of animals. I proceed to offer an approach through which this recognition may be effected in law: it is argued that, though a constitutional amendment would be desirable, it is not necessary, The existing constitutional and common law framework can be interpreted convincingly to recognise the legal personhood of non-human animals and their capacity to be rights-bearers. A key problem that arises, however, is whether South African society is ready to embrace the full implications of this recognition. The legal concept of 'progressive realisation' in respect of animal rights is proposed as offering the possibility of ensuring greater protections for animals through recognising their dignity and personhood whilst embracing a gradualist approach towards the full realisation of their rights, thus preventing a wholesale disjunction between the law and the attitudes of wider South African society. 


\section{Is Legal Personality Arbitrarily Confined to Humans?}

\section{(a) The concept of the person in South African law}

Sinclair defines a person in law as 'a being, entity or association which is capable of having legal rights and duties' ${ }^{, 8}$ whereas things 'neither have, nor are they capable of having rights and duties'. ${ }^{9}$ Cronje prefers to distinguish between a legal subject - 'any entity that can have rights, duties and capacities' - and a legal object - 'any object which has economic value for human beings and upon which the law has not conferred the capacity to have rights, duties and capacities and which can therefore not participate in legal and commercial traffic'.

Legal personality is itself a construct ${ }^{11}$ and this is no more evident than in the fact that there are two categories of persons that exist in South African law: natural and juristic persons. A natural person has traditionally consisted of all human beings from the time of birth until death; a juristic person is 'made up of those entities or associations of person which, having fulfilled certain requirements are allowed by the law to have rights and duties apart from the individuals who compose them or direct their affairs'. ${ }^{12}$ The existence of juristic persons highlights the fact that the law may recognise the legal personality of an entity where this is socially desirable. It is important, however, to understand that the nature of the legal personality attributed to juristic persons differs markedly from that of natural persons. Whilst a company is allowed to sue or be sued in its own name, it is always certain natural persons who act on behalf of and whose interests are involved in such transactions. Were there no natural persons, there could be no juristic persons whilst the converse is certainly not true. ${ }^{13}$

Juristic legal personality is in many ways a form of 'legal fiction' whereby rights and duties are attributed to entities such as companies and close corporations. This fiction is, however, important as it is the basis upon which the interests of a company can be taken account of in its own right, distinct from the natural persons that make it up or act on its behalf. Similarly, recognition 5 .

9 Ibid 3.

10 DSP Cronje \& J Heaton The South African Law of Persons 2 ed (2003) 2.

11 Sinclair (note 8 above) 4 states that 'the law is at liberty to confer legal personality upon any entity that it sees fit, thereby enabling it to acquire rights and duties on its own account'. See also Cronje \& Heaton ibid 4.

12 Sinclair ibid 5.

13 The Constitutional Court has in certain cases pronounced upon the protections the Bill of Rights affords juristic persons though it has in these contexts generally affirmed the primacy of the interests of natural persons. See Investigating Directorate: Serious Economic Offences v Hyundai Motor Distributors 2001 (1) SA 545(CC) para 17 where the court held that whilst privacy rights were applicable to juristic persons, they were not the bearers of human dignity and consequently, ' $[\mathrm{t}]$ heir privacy rights can never be as intense as those of human beings'. Similarly, see First National Bank of SA Ltd t/a Wesbank v Commissioner, South African Revenue Service; First National Bank of SA Ltd t/a Wesbank v Minister of Finance 2002 (4) SA 768 (CC) para 45 where property rights of juristic persons were recognised on the grounds that 'property rights of natural persons can only be fully and properly realised if such rights are afforded to companies as well as to natural persons'. 
as a natural person means that any such person is recognised as having legal interests in their own right. All and only persons can claim the protection of the fundamental rights contained within the Bill of Rights, the most significant protections afforded by our legal system. ${ }^{14}$ Furthermore, generally, common law rights attach only to persons. ${ }^{15}$

In our law, thus, legal personhood appears to be the most important status one can have in that it is the prerequisite for granting legal protections to an entity in its own right. Since juristic personality is really dependent upon natural personality, the primary category or status in our law is that of natural personhood. The determination of who has this status has major implications for those included as well as those excluded. It is thus critical that there be solid reasons for the extension of this category.

It is important to recognise that there is a fundamental ambiguity in the meaning of the concept of personhood in the law. It is generally taken to refer to a being or entity capable of having legal rights or duties: however, it is unclear whether such a being or entity must be capable of having both legal rights and duties or whether such a being or entity must be capable of having either legal rights or duties? Most authors seem to fudge the matter without recognising an important distinction that underlies this ambiguity. In the case of natural persons, an individual that is capable of having duties must have certain sophisticated mental abilities including the ability to deliberate about a course of action morally, and the ability to choose to act according to the outcomes of this deliberation. Those who can act out of a sense of moral obligation are often referred to as 'moral agents'. ${ }^{16}$ Given their capacities, moral agents generally are the bearers of responsibility for a course of action adopted.

Moral patients, on the other hand, 'lack the prerequisites that would enable them to control their own behaviour in ways that would make them morally accountable for what they do'. ${ }^{17}$ Nevertheless, though unable to act out of a sense of duty, they have certain rights that moral agents must respect. ${ }^{18}$ The membership of the class of moral agents and moral patients are clearly different: in relation to human beings, moral agents generally include all adult, rational human beings whereas moral patients would include infants, young children, the senile and those with severe mental impairments.

Section 8(4) of the Constitution of the Republic of South Africa, 1996, provides that 'a juristic person is entitled to the rights in the Bill of Rights to the extent required by the nature of the rights and the nature of the juristic person'. There is no express provision governing the applicability of the Bill of Rights to natural persons yet this is implied (see part III below for further discussion of this), and some of the statements of the Constitutional Court quoted in note 13 above.

15 DSP Cronje 'Persons' in WA Joubert et al The Law of South Africa (1999) para 341 states that '[t]he importance of being a person in the eyes of the law lies in the fact that only a person can have rights, duties and capacities and can therefore participate in legal intercourse'.

16 See T Regan The Case for Animal Rights (1984) 151. See also P Cavalieri The Animal Question (2001) 28-31.

17 Regan ibid 152.

18 I shall discuss later the basis for the attribution of rights to moral patients: in brief, it is usually the recognition that they have certain interests that leads to the recognition of their rights. 
The law as it currently stands in South Africa recognises that 'all human beings irrespective of, for example, their age, mental capacity and intellectual ability are recognised as legal subjects, ${ }^{19}$ That means that both human beings who are moral agents and those who are moral patients are recognised as persons in our law. If this is so, then it means that the concept of the person must refer to an entity that is capable of having either legal rights or duties and that such a person need not be capable of having both legal rights and duties. ${ }^{20}$ It also means that our law recognises that rights may be attributed to beings without sophisticated mental abilities. ${ }^{21}$ If, at least, some animals are moral patients and are capable of having certain rights, then this means that they should also be recognised as persons in our law unless there is some good reason to deny them this status. It is thus necessary to consider the current position of animals within our law, a matter examined in the next section.

\section{(b) Are animals correctly classified as things in our law?}

Being a member of the human species has generally been seen to be both a necessary and sufficient condition for being a natural person in law. ${ }^{22}$ Animals have thus generally been classified as 'things', 'property' or 'legal objects' in terms of the law. ${ }^{23}$ This means that their interests are not considered in their own right nor are they entitled to the protections of the fundamental rights in the Constitution as well as most common law and statutory rights. ${ }^{24}$

Though this was the classification of animals in Roman and Roman-Dutch law, there is some dispute amongst academic authors concerning the impact of the Animal Protection Act 71 of $1962^{25}$ upon the status of animals in South African law. The current Act prohibits a range of acts that, whether done inten-

19 Cronje \& Heaton (note 10 above) 4.

20 Some will find this difficult to accept as they believe that the concept of personhood involves the notion of reciprocity and the capacity to fulfil moral duties. Rawls, for instance, argues that persons are to be conceived of as free and equal citizens: they are free in virtue of having two moral powers (a capacity for a sense of justice and for a conception of the good) and the powers of reason (judgment, thought and inference connected with these powers); they are equal in that they have these powers to the requisite minimum degree to be fully cooperating members of society ( $\mathrm{J}$ Rawls 'Justice as Fairness: Political not Metaphysical' (1985) 14 Philosophy and Public Affairs 223, 234. See also J Rawls Political Liberalism (1993) 18-20 and 29-34). These capacities would seem to involve the notion of being capable of fulfilling moral obligations. Thus, if Rawls is correct, then it seems that the idea of 'the person' implicit in democratic culture involves the notion of being able to have duties. Yet, the inclusion of all human beings including infants and the mentally ill within the category of natural persons demonstrates clearly that the Rawlsian notion of the person - whilst having its own importance - does not capture the conceptual contours of the concept of natural personhood in South African law.

21 Clearly having duties requires certain sophisticated mental abilities. If children and the mentally ill are regarded as legal persons, it must mean that they are capable of having rights within our law. In terms of jurisprudential theory, this seems to show that South African law does not adopt the 'Will' theory of rights but regards the possessions of significant interests as sufficient for being capable of having rights (ie it supports the Interest theory). For the distinction between the two theories, see M Kramer, NE Simmonds \& H Steiner A Debate Over Rights (1998).

22 Sinclair (note 8 above) 4-5 and Cronje \& Heaton (note 10 above) 4.

23 Sinclair ibid 3.

24 Ibid 3-4.

25 This Act replaced the Prevention of Cruelty to Animals Act 8 of 1914. 
tionally or negligently, inflict 'unnecessary suffering' upon animals. ${ }^{26}$ The dispute that has arisen concerns whether the Animal Protection Act is designed to protect animal interests directly and thus elevates animals to the status of personhood through conferring certain legal rights upon them or whether the prohibitions on cruel treatment are simply designed to protect certain human or community interests. ${ }^{27}$ This dispute may be said to reflect two views of the obligations that human beings have concerning animals: the former view may be referred to as the 'direct duty' view in terms of which human beings have direct duties towards animals to accord them particular forms of treatment; ${ }^{28}$ the latter view is known as the 'indirect duty' view in terms of which no duties are owed directly to animals but behaviour towards them is regulated for the sake of the sensibilities of other human beings or for purposes of ensuring certain standards of behaviour towards fellow human beings. ${ }^{29}$

The purpose of the Animal Welfare Act was considered in the case of $R v$ Moato $^{30}$ where the decision of Van Den Heever J (with Fischer JP concurring) clearly exemplified the 'indirect duty' approach: '[t] he aim of the legislation was not to elevate animals to legal personhood and this prohibition is not designed to give them protection. The aim was clearly to forbid a legal person to act with such cruelty towards an animal that the finer feelings and sensibilities of their fellow humans would be harmed thereby,. ${ }^{31}$ This dictum was approved and followed in $S v E d m u n d s^{32}$ where Miller J states that the object of the Act 'was not to elevate animals to the status of human beings but to prevent people from treating animals in a manner which would offend the finer sensibilities of society,. 33

However, this rationale for the existence of Animal Protection legislation cannot withstand critical scrutiny for a range of reasons. ${ }^{34}$ First, if the ration-

26 See s 2(1)(r) of the Act that is a catch-all provision for a range of cruel behaviours.

27 See the discussion and implications for the personhood of animals in AO Karstaedt 'Vivisection and the Law' (1982) 45 THRHR 349; JMT Labuschagne 'Regsubjektiwiteit van die Dier' (1984) 47 THRHR 337; G Pienaar 'Behoort Diere as Regsubjekte erken te word?' (1985) 48 THRHR 199; JA Robinson 'Labuschagne en Diere as Regsubjeckte' (1985) 48 THRHR 343; JMT Labuschagne 'Regsobjekte Sonder Ekonomiese Waarde en die Irrasionele by Regsdenke' (1990) 53 THRHR 557; and K Hopkins 'Some New Thoughts on Protecting Animals Against Cruelty: a Human Rights Perspective’ (2003) 24 Obiter 431.

28 See T Regan 'Progress Without Pain: The Argument for Humane Treatment of Research Animals' (1986) 31 St Louis ULJ 513, 515.

29 See, for example, I Kant Lectures on Ethics (trans L Infield 1963) 239.

30 1947(1) SA 490 (O) 490.

31 The quote is a free translation of the following passage at 492 in Afrikaans: '[d]ie oogmerk van die wetgewing was nie om diere tot regsgenote to verhef nie en hierdie verbod is nie bedoel om aan hulle beskerming to verleen nie. Die oogmerk was klaarblyklik om to verbied dat een regsgenoot so ongenadig teenoor diere optree dat hy daardeur die fyner gevoelens en gewaarwordings van sy medemense leed aandoen'.

$321968(2) \mathrm{PH} \mathrm{H} 398(\mathrm{~N})$.

33 Ibid H398, 758. However, see National Council of Societies for the Prevention of Cruelty to Animals $v$ Peter Openshaw (462/07) 2008 ZASCA 78 RSA (NSPCA) footnote 13 where Cameron JA reads Miller J as not endorsing Van Den Heever's claim that the Act does not meant to confer protection on animals.

34 The discussion here follows the short but incisive critique of this rationale by AO Karstaedt (note 27 above). 
ale is to protect individual sensibilities from being offended, it is unclear why private acts of cruelty are prohibited. 'Surely private acts of cruelty would be permitted if the legislature's purpose was to protect people from affronts to their sensibilities, ${ }^{35}$

Secondly, the question arises in a constitutional democracy as to why one person's actions should be restricted for the sake of not offending the sensibilities of others in society. The right to freedom of speech, ${ }^{36}$ and the right to freedom of conscience, religion, belief and opinion ${ }^{37}$ would all be meaningless if individuals were not allowed - within reasonable limits - to act in ways that at times are controversial and may offend the feelings of others. ${ }^{38}$ The fact that others may be offended or distressed by one's conduct cannot in and itself provide a sufficient basis to ground a legal prohibition on such conduct. ${ }^{39}$ There must be valid reasons why the causing of such offence cannot be tolerated within a society. The question thus arises as to what reasons underlie the offence caused to many people by cruelty to animals.

Feinberg explains that it is hard to account for the existence of strong sensibilities against animal cruelty in the absence of a belief on the part of such individuals that animals deserve protection 'in their own right and for their own sakes. ${ }^{40}$ Moreover, if there were no basis for such feelings and they failed to capture something of importance, it is unclear why their mere existence should impose legal obligations on others to respect them. Karstaedt puts the point well as follows:

[e]ither our sensibilities are disturbed when we witness animal cruelty because we recognise that animals are capable of suffering, and do in fact suffer, in much the same way as humans do, or else these sentiments are misplaced and absurd. If it is the former, how can we rationally continue to regard that suffering in a completely different light from human suffering? What justification can there be for refusing to take that suffering into account and for continuing to interpret anti-cruelty legislation in human terms? If it is the latter, why should the law then protect these sensibilities? Why does the law not, for instance, prohibit people from breaking their expensive antiques on the ground that such conduct might upset other people? ${ }^{41}$

It is not the sensibilities of individuals per se but what underlies those sensibilities in relation to animals that provides compelling reasons for the enactment of Animal Protection legislation. To explain why cruelty to animals should

35 Ibid 351

36 Section 16 of the Constitution.

37 Section 15 of the Constitution.

38 In the context of freedom of expression, the majority held in South African National Defence Union $v$ Minister of Defence 1999 (4) SA 469 (CC) para 8 that 'the corollary of the freedom of expression and its related rights is tolerance by society of different views. Tolerance, of course, does not require approbation of a particular view. In essence, it requires the acceptance of the public airing of disagreements and the refusal to silence unpopular views'. Similarly, it has been held in Christian Education South Africa v Minister of Education 2000 (4) SA 757 (CC) para 19 that the right to freedom of religion, conscience, belief and opinion includes both 'the right to have a belief and the right to express such belief in practice'.

39 See for instance J Waldron 'Mill and the Value of Moral Distress' in J Waldron (ed) Liberal Rights: Collected Papers (1993) 115.

40 J Feinberg (1980) 'The Rights of Animals and Unborn Generations' in J Feinberg (ed) Rights Justice and the Bounds of Liberty (1980) 161-2.

41 Karstaedt (note 27 above) 352. See also P Cavalieri (note 16 above) 50. 
be prohibited, it is necessary to recognise that animals are beings capable of suffering in their own right and that certain forms of ill-treatment towards them are unacceptable. ${ }^{42}$

Some have tried to resist this conclusion by arguing that animal welfare statutes seek to prohibit cruelty to animals as such cruelty can encourage a disposition within individuals to act in a cruel or violent manner towards other humans. This Kantian view holds that since only human beings are rational agents, only they have intrinsic value or 'dignity'. ${ }^{43}$ Yet, behaviour towards animals has an impact on the actions of individuals towards other humans: ' $[\mathrm{h}] \mathrm{e}$ who is cruel to animals becomes hard also in his dealing with men ... Tender feelings towards dumb animals develop humane feelings towards mankind, ${ }^{44}$

In recent years, some empirical research has been done which shows a correlation between instances of animal abuse and domestic violence towards women and children. ${ }^{45}$ There are also some studies showing that serial killers commenced their violent activities with cruel behaviour towards animals. ${ }^{46}$ This research is important and suggests there can indeed be a link between cruel actions towards animals and human beings. The important question that arises relates to what could explain this link.

Robert Nozick famously questions the indirect duty rationale by arguing that there is no reason why cruel treatment towards animals should inevitably lead to cruel behaviour towards human beings provided that a person keeps a clear distinction in mind between animals and human beings. He asks,

[i]f I enjoy hitting a baseball squarely with a bat, does this significantly increase the danger of my doing the same to someone's head? Am I not capable of understanding that people differ from baseballs, and doesn't this understanding stop the spillover? Why should things be different in the case of animals? $?^{47}$

However, the problem with this argument is that animals are not baseballs. The empirical research that connects cruelty towards animals with that towards humans suggests that the line between the animal and the human cannot be drawn so strongly as to prevent animal cruelty from having an impact on human behaviour. The reason for this, I would argue, should not

This rationale is borne out by some of the history concerning animal welfare legislation: see, for instance, M Radford Animal Welfare Law in Britain (2001) 26ff. He states at 270 that '[t]he body of legislation designed to protect them from cruelty and to promote their welfare is predicated in Britain on an acceptance, underpinned by scientific opinion, that animals are sentient'.

43 See below for further discussion of this notion when I discuss Kant's view of dignity.

44 I Kant (note 29 above) 240.

45 See, for instance, R Lockwood 'Animal Cruelty and Violence Against Humans: Making the Connection' (1999) 5 Animal Law 81, 85; CA Lacroix 'Another Weapon for Combatting Family Violence: Prevention of Animal Abuse' (1998) 4 Animal Law 1, 7; and AJ Dryden 'Overcoming the Inadequacies of Animal Cruelty Statutes and the Property-based View of Animals' (2001) 38 Idaho L Rev 177, 185 .

46 See R Lockwood ibid 82-3: '[r]etrospective studies of serial killers, mass murderers, arsonists, serial rapists, and sexual homicide perpetrators indicated animal abuse was often a childhood characteristic of these violent offenders'.

47 R Nozick Anarchy State and Utopia (1974) 36. 
seem surprising: animals are not inanimate objects but sentient creatures. ${ }^{48}$ As such, they are sufficiently similar to human beings such that they have significant interests in not being subjected to suffering. Failing to respect such interests in the case of animals can lead to a failure to respect such interests in the case of humans precisely because of the sufficient similarity between human beings and animals. ${ }^{49}$

The similarity, however, provides the reason why the indirect duty rationale itself is inadequate. For, once we recognise a similarity between the human and animal necessary to provide support for the rationale, the question becomes why is it that we only have direct duties towards human beings? A plausible line of argument seems to run as follows: according to the indirect duty rationale, the point of prohibitions on animal cruelty is to prevent cruel behaviour towards human beings. Yet, it is the sufficient similarity between the interests animals have in avoiding suffering and the interests human beings have in

I use the word sentient to refer to the notion that a creature has a subjective conscious awareness of the world, that 'there is something it is like to be' the creature in question (see T Nagel 'What is it Like to be a Bat?' in T Nagel (ed) Mortal Questions (1979) 165-6). This is essential if animals are going to be able to experience pleasure and pain, and that capacity is a precondition for being able to have interests in their own right (see P Singer Animal Liberation (1995) 7). Whilst there are still some in the scientific community who believe that animal are automatons with no capacity to feel, there are strong philosophical and scientific arguments that now discredit this counterintuitive position. Increasingly, evidence shows that non-human animals are capable of a wide range of mental states, ranging from mere sentience to sophisticated capacities such as beliefs, desires and emotions. See the excellent discussion of the wide range of mental states that can be attributed to animals in D DeGrazia Taking Animals Seriously: Mental Life and Moral Status (1994) 97-210. See also M Dawkins 'The Scientific Basis for Assessing Suffering in Animals' in P Singer (ed) In Defense of Animals (2006) 26; Radford (note 42 above) 262-88; L Carbone What Animals Want (2004); and T Regan (note 16 above) 34-82. A more lengthy discussion of the mental lives of animals lies beyond the scope of this article.

49 An anonymous referee suggested a thought experiment where we could imagine robots (that looked like humans perhaps), which are not sentient but closely mimic human behaviour. It would be possible, in such an instance, for violent actions towards such a robot to be prohibited on grounds that they would tend to result in cruelty towards humans. The explanation here for such a prohibition could not be that they were sentient but rather would have to be based upon some kind of perceived similarity to humans. Could the same not be true for animals, allowing the indirect duty theorist the opportunity to resist the conclusion that animals are protected because of interests they possess in their own right? Clearly, there is a large difference between animals and the robot in this example in that all available scientific evidence makes it clear that animals do not simply 'appear' to experience suffering but they actually do experience suffering (see DeGrazia ibid) and most human beings recognise this to be the case. The thought experiment - though somewhat ambiguous - however, far from countering my argument, actually provides support for it. For, it rests upon a behavioural assumption that cruel action towards the robot would lead to cruel actions towards human beings. If we know the robot lacks the capacity for sentience, it is difficult to see why this assumption should hold true (we would hardly be prohibited, for instance, from cutting up a blow-up doll that resembles a human being). Perhaps it could be that we know intellectually that the robot is not sentient but it is sufficiently human-like to lead us to perceive (mistakenly) that it is being hurt. If this is the case, then the spill-over effect is still likely only because we are likely (erroneously) to perceive the robot as having interests that are being violated. Similarly, if we do not know the robot lacks the capacity for sentience, then the behavioural assumption may hold true but for the reason that we perceive the robots to have interests in its own right. It is the fact that cruel action appears callously to disregard the 'interests' of the robot that leads to the possibility that this may spill-over into cruel behaviour towards other human beings. Either way, the spill-over effect is only likely as a result of the fact that we perceive (erroneously) that the robot has an interest in its own right in not being subjected to cruel treatment. 
avoiding suffering that makes it likely that there will be a spill-over from cruel behaviour towards animals to cruel behaviour towards humans. Yet, if this sufficient similarity is reason to fear such a spill-over, then it seems that what matters in these circumstances are the interests of both animals and humans in avoiding suffering. If this interest is sufficient to ground a prohibition against cruel behaviour in the case of human beings, why is it not sufficient to ground such a prohibition in the case of other sentient animals? If there is no good reason to distinguish between the two cases, then it seems that the indirect duty argument ultimately collapses into a direct duty argument.

Recognising the inadequacy of the indirect duty view, Cameron $\mathrm{J}$, in a recent minority judgment, held that the view expressed in Moato that the Animal Protection Act is 'not meant to confer protection' on animals ${ }^{50}$ is 'erroneous'. ${ }^{51}$ He construed the purpose of animal welfare legislation as being designed to protect the welfare of animals directly, though, he claimed that the legislation does not seek to confer rights on animals. ${ }^{52}$ He held that 'the statutes recognise that animals are sentient beings that are capable of suffering and of experiencing pain. And they recognise that regrettably, humans are capable of inflicting suffering on animals and causing them pain. The statutes thus acknowledge the need for animals to be protected from human ill-treatment'. ${ }^{53}$ Despite this, Cameron found that 'like slaves under Roman law, they are the objects of the law, without being its subjects ${ }^{54}$ Since animals do not have a voice of their own, the legislature sought to appoint the Societies for the Prevention of Cruelty to Animals as their 'guardian and their voice'.

These statements are some of the most far-reaching judicial pronouncements on the status of animals in our law in recent times and represent a progression from the earlier cases. Nevertheless, they are deeply puzzling: on the one hand, Justice Cameron recognises the capacity of animals to suffer as the ground for the prohibition on cruel treatment. ${ }^{56}$ This is an important recognition that animals have interests that the law protects in their own right. Yet, at the same time, he claims that animals remain legal objects, reduced to the status of 'property' and having no rights in terms of the law. There are two central problems with this position.

First, if the duties to animals arise as a result of their interests in not being subject to suffering, then it is unclear why such duties do not confer rights upon animals not to be subjected to suffering by human beings. It is generally accepted that duties and rights are correlative: in terms of a Hohfeldian conception of rights this would imply that a duty towards animals to avoid

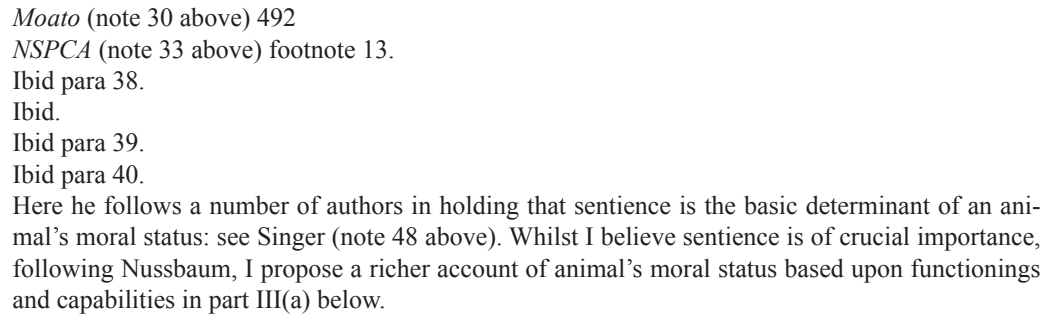
mal's moral status: see Singer (note 48 above). Whilst I believe sentience is of crucial importance, following Nussbaum, I propose a richer account of animal's moral status based upon functionings and capabilities in part III(a) below. 
treating them cruelly would logically entail that they have a correlative right not be subjected to cruel treatment. ${ }^{57}$ Even if we reject a strict correlativity between duties and rights in some cases (such as those involving general positive obligations upon individuals), ${ }^{58}$ it appears clear that such correlativity does hold where general negative obligations are involved. A duty to avoid inflicting suffering on an animal applies to every animal one comes into contact with: thus, every animal can claim a right to avoid having suffering inflicted upon it. If Cameron wishes to reject the indirect duty rationales for protecting animals - as, it has been argued is in fact correct in principle - then direct duties must be owed to animals to avoid subjecting them to unnecessary suffering. If that is so, then it seems to follow that such duties entail correlative rights on the part of animals. ${ }^{59}$

The second problem lies with the analogy suggested by Cameron: it provides the exact reason why it is of importance to change the status of animals in our law. Slaves in Roman law were regarded as property. ${ }^{60}$ The new South African legal dispensation precisely rejects the notion that any human beings should be regarded as property: all human beings have fundamental interests that are deserving of legal protection and as such they are legal subjects rather than legal objects. If, as has been argued, animals also have fundamental interests that are deserving of legal protection, on what basis can we justify consigning their status to that of legal objects? It cannot be because they do not have a voice of their own as young children cannot speak for themselves or claim their rights yet they are regarded as legal subjects with rights of their own. The guardianship duties of parents, the state and the courts are designed to protect the interests of such children even though they lack a voice to represent their own interests. A guardianship model might similarly be appropriate for protecting the interests of animals in law but this does not entail that they lack rights. The fact that animals have interests of their own involves recognising that they are not simply property and that duties are owed to them directly. If this is so, then this provides reason to recognise that they have rights and consequently to challenge the status of animals as legal objects. then $\mathrm{X}$ has a right to be free from any such interference by $\mathrm{Y}$ '.

58 The classic example here would be a duty to give charity which each agent has but no particular individual has a right to my charity. These are often referred to as 'imperfect obligations' and are often discussed in relation to the fourth example Kant gives in his 'Groundwork of the Metaphysics of Morals' (in I Kant Practical Philosophy (trans MJ Gregor, 1996) (1785) 75). The general obligation is to no one in particular and hence no one in particular can claim a right to a specific performance. Correlativity could be maintained by attributing rights in this instance to a collective such as the community or humanity. Even if we do not wish to follow this route, it is clear that correlativity does apply when there is a specific obligation placed upon a person towards a specific other (or every other) not to perform a particular action or to perform a particular action as is the case of the obligations discussed in the text.

59 Labuschagne (note 27 above) 340 states that 'indien dit verkeerd is om op a sekere wyse teenoor 'n dier op te tree, dit gesê kan word that daardie dier die reg het dat [dit] (sic) nie op so 'n manier opgetree word nie'.

Sinclair (note 8 above) 4 . 
It seems that there is a reticence on the part of Cameron $\mathrm{J}$ (despite his generally progressive judgment) to follow through on the logic of his own holding that the Animal Protection Act is designed directly to protect the interests of animals in not being subjected to suffering by human beings. Yet, if we are to move into a new era based upon what can be rationally justified rather than what has existed until now, then it is important to follow through the logic of Cameron's position for the category of personhood in our law. A person is clearly in our law an entity that is capable of having either rights or duties (not necessarily both). Children have interests that give rise to legal rights and so are recognised as persons. If animals too have similar interests that can give rise to legal rights, ${ }^{61}$ then on what basis can we deny recognising them as persons? If we cannot find a satisfactory reason for the exclusion of non-human animals, then such an exclusion will be arbitrary and ill-founded and must be rejected in the new constitutional order.

Is it possible to avoid such arbitrariness? To do so, it is important to understand that underlying the law's conferral of the status of natural personhood to all and only humans is an oft-made assumption concerning the special status of human beings as a class. To defend the connection between personhood and human-ness, it is necessary to defend the thesis that all humans, simply by virtue of their species membership, are entitled to a special status and treatment within our law. Sadly, this line of thinking - as flawed as it is ethically - is something that many see as having been given constitutional sanction in the new legal order through the emphasis placed on the value of 'human dignity'. I now turn to consider this concept and whether there is any rational justification for thinking of dignity as something that should exclusively be confined to human beings.

\section{The Arbitrariness of 'Human' Dignity}

The South African Constitution generally refers to the value of 'human dignity' rather than dignity as such. ${ }^{62}$ This is consistent with the three human rights instruments at international law often referred to as the 'International Bill of Rights' - the Universal Declaration of Human Rights, ${ }^{63}$ the International Covenant on Civil and Political Rights ${ }^{64}$ and the International Covenant on Economic, Social and Cultural Rights. ${ }^{65}$ The Preamble of each of these docu-

The focus of this article is on the legal rights that animals should be recognised as having under our law. It is not simply about their moral rights against us though the existence of such moral rights particularly where the interests that are protected are of great importance - would provide a strong case for their being entrenched in law. As has been argued in this section, the existing statutory framework can already be seen to confer certain legal rights upon animals once we draw out the assumptions underlying it.

62 Section 1 recognises human dignity along with equality and freedom as a foundational value; 7 recognises it as a foundational value in the Bill of Rights; $s 10$ is headed human dignity and recognises a right to have one's dignity respected and protected; and it is a value to be considered in s 36 when deciding whether a limitation of a right is reasonable or justifiable.

63 See $<$ http://www.un.org/Overview/rights.html $>$.

64 See $<$ http://www.unhchr.ch/html/menu3/b/a_ccpr.htm $>$.

$65 \mathrm{See}<\mathrm{http}: / /$ www.unhchr.ch/html/menu3/b/a_cescr.htm $>$. 
ments refers to the 'recognition of the inherent dignity and of the equal and inalienable rights of all members of the human family' ${ }^{66}$ The rights contained in these documents are claimed to derive from the inherent dignity of the human person' and all human beings are said to be 'born free and equal in dignity and rights'. ${ }^{67}$

The South African Constitutional Court has on several occasions sought to interpret the meaning and function of dignity within our constitutional order. In the National Coalition judgment, ${ }^{68}$ Justice Ackermann, writing for the majority, states that dignity [a]t its least, 'requires us to acknowledge the value and worth of all individuals as members of our society'. ${ }^{69}$ Similarly, in the Dawood judgment, ${ }^{70}$ Justice O'Regan holds that the Constitution asserts dignity 'to invest in our democracy respect for the intrinsic worth of all human beings, ${ }^{71}$ Thus, it is clear from these two dicta which represent much of what has been said about dignity in South African courts, that 'dignity' is essentially about the recognition of worth and the consequent treatment that must be accorded to individuals who have such worth. ${ }^{72}$ These judgments, as do the International Covenants, assert that it is all and only human beings that have such worth and are required to be treated in accordance with that worth.

Assumptions of worth have a chequered history. The assertion of the dignity of all human beings in post-World War II human rights documents represented a reaction against the Holocaust and the War itself, both of which undeniably saw the massive devaluation in human life. Dignity was designed as a corrective to assert the universal value of all human-kind. However, what was a corrective also had interesting continuities with past assumptions that underlay the Nazi regime. ${ }^{73}$ The concept of dignity was closely associated with the notion of rank, status and social hierarchy in 17th century Europe. Those with dignity had a special status and were included within the aristocratic class. The Nazi regime could be said to have built on this hierarchy but broadened it to include all those it defined as Aryan: all Aryans were to be regarded as having special worth and to be treated accordingly. Of course, anyone who was not an Aryan was designated as being of lesser or no worth and could be treated with little or no respect. Apartheid South Africa was quite similar: equal worth was to be accorded to all whites, whilst all other racial groups were lesser and could be treated accordingly. The history of racism and fas-

68 National Coalition for Gay and Lesbian Equality v Minister of Justice 1999 (1) SA 6 (CC).

69 Ibid para 28

70 Dawood, Shalabi and Thomas v Minister of Home Affairs 2000 (3) SA 936 (CC).

71 Ibid para 35

72 I shall only be considering the concept as it is used in this sense. There are a range of meanings and functions that 'dignity' performs in our constitutional order including an important sense in which it prohibits the humiliation of individuals. For a more detailed discussion, see S Woolman 'Dignity' in S Woolman et al (eds) Constitutional Law of South Africa 2 ed (2006) chapter 36 1, 6, 25.

73 See JQ Whitman 2003 'On Nazi "Honour" and the New European "Dignity" in C Joerges \& NS Ghaleigh (eds) Darker Legacies of Law in Europe: The Shadow of National Socialism and Fascism over Europe and its Legal Traditions (2003) 243. 
cism thus is predicated upon assumptions of worth. These evil ideologies, however, restrict worth unjustifiably and without reason to a particular class of human beings, anyone outside that class is of lesser worth and can as a result be subject often to severe forms of maltreatment.

It is important to diagnose what the problem has been here: the injustice that resulted from these ideologies involved treating individuals who in fact had worth and were deserving of equal concern and respect as if they did not have such worth. To try and remedy the defect in these ideologies thus requires a theory as to who in fact has such worth. If we develop another class that is equally unjustifiable, and we exclude from our legal system those that are entitled to decent treatment, we continue to perpetrate injustice that is akin to that committed in the name of Nazism or apartheid. The notion of 'human dignity' that has been used to argue that worth attaches to all and only humans thus requires justification. ${ }^{74}$ Why is it that we should value all and only human beings and only confer on them rights to decent treatment?

\section{(a) The category approach}

The first approach often adopted towards the notion of 'human dignity' may be termed the 'category approach' and would assert simply that human beings have an intrinsic worth that derives from their being members of the species homo sapiens. It is simply by virtue of the group one belongs to - in this case the species homo sapiens - that one is entitled to certain treatment.

However, this reasoning is wholly unpersuasive. First, the category approach involves simple assertion without justifying why the category of homo sapiens is sufficient to determine worth and the type of treatment human beings are to be accorded. Without any justification, it seems arbitrary to focus on a particular group: why not assert that intrinsic worth lies in class of mammals or of human males? On what basis do we conclude that the value of a being and the consequent treatment to be accorded to that being depends upon a particular category? The category approach cannot alone answer these questions.

The central problem for all human rights discourses that seek to find their foundations in the category approach is that ultimately, as Joel Feinberg notes, 'it is not grounded in anything more ultimate than itself, and it is not ultimately justifiable'. ${ }^{75}$ Beyleveld and Brownsword, in their outstanding discussion of the concept of human dignity, argue that there are two particular problems with this conception. ${ }^{76}$ The first is that respect for rights will depend entirely on the contingent acceptance that people have a particular attitude towards other

South African academic writers have not generally analysed the question as to why all and only human beings are regarded as having dignity and have largely been concerned with debating its indeterminacy or the way in which dignity functions in relation to other constitutional values and rights: see, for instance, D Davis 'Equality: The Majesty of Legoland Jurisprudence' (1999) 116 SALJ 398; S Cowen 'Can Dignity Guide South Africa's Equality Jurisprudence' (2001) 17 SAJHR 34; and S Liebenberg 'The Value of Human Dignity in Interpreting Socio-Economic Rights' (2005) 21 SAJHR 1.

75 J Feinberg Social Philosophy (1973) 94.

76 D Beyleveld \& R Brownsword Human Dignity in Bioethics and Biolaw (2001) 22-3. 
human beings that cannot in itself be justified. ${ }^{77}$ The second problem is the unjustifiable elevation of the human as worthy of value above other animals: why is such a claim not simply an unjustifiable prejudice akin to racism or sexism? ${ }^{78}$

It is important to understand that the structure of the argument is the same in either case: a racist asserts the relevance of race to justify differential and superior treatment for his own race; a speciesist, similarly, asserts the relevance of species to justify differential and superior treatment for his own species. Yet, the category approach provides no grounds for asserting the relevance of the particular biological characteristic in either case. If the idea of human dignity is simply asserted as conferring a special status upon human beings with no further justification, then it creates a major gap at the basis of our legal system. If asked to justify why all and only humans are entitled to fundamental rights, we are on no more solid basis than a person who claims that white people have a special extra soul that grants them greater worth: both are faith-based notions with no philosophical grounding and cannot be used to ground our legal rules in a secular constitutional democracy committed to a culture of justification. ${ }^{79}$

\section{(b) The rational agency approach}

It is thus hard to see how a defensible conception of 'human dignity' or worth can be based on species membership alone. More promising philosophical theories do not seek to attribute worth on the basis of group membership alone but rather seek to identify certain personal characteristics that ground attributions of worth to a creature. A defender of 'human dignity' could thus seek to make the following argument: worth or dignity resides in beings that have particular capacities; only human beings have these capacities, and thus only human beings have dignity or worth. Most commonly proponents of this view attempt to identify these capacities as involving inter alia the ability to use language in a sophisticated manner, the ability to enter into complex and abstract rational thought, or the capacity for fully autonomous action. In evaluating this approach, I shall refer to the capacity governing the ascription of worth as being 'rational agency' a notion familiar from Kant's philosophy which is often seen to provide the most compelling origins of the dignity concept.

Ibid.

Ibid. See also P Singer (note 48 above) 9 who famously wrote: 'Racists violate the principle of equality by giving greater weight to the interests of members of their own race when there is a clash between their interests and the interests of those of another race. Sexists violate the principle of equality by favouring the interests of their own sex. Similarly, speciesists allow the interests of their own species to override the greater interests of members of other species. The pattern is identical in each case'.

It may be true that the Judeo-Christian tradition ultimately is responsible for the attitudes that only human beings have dignity yet a secular constitutional democracy should not use particular religious ideas that lack adequate philosophical grounding to determine the legal rights or status of particular groups. For writing prior to the advent of the Constitution on this topic that fails to respect the religious/secular divide, see Pienaar (note 27 above) and Robinson (note 27 above). 
For Kant, things either have a price or dignity: ${ }^{80}$ what has a price can be replaced by something else; what 'on the other hand is raised above all price and therefore admits of no equivalent has a dignity'. ${ }^{81}$ The concept of dignity for Kant is clearly linked to the notion of full personhood: ${ }^{82}$ only rational beings may be persons because, he says, 'their nature already marks them out as an end in itself' ${ }^{83}$ Beings that are rational have absolute worth: all other beings without reason have only 'relative worth'. ${ }^{84}$ Dignity for Kant also relates to the notion that individuals can govern their own conduct through adherence to the moral law: this capacity for self-determination or autonomy 'is therefore the ground of the dignity of human nature and of every rational nature. ${ }^{85}$ The recognition of the dignity of humanity in turn implies that it is only towards autonomous human beings that we owe direct duties to treat them as an end and never merely as a means. ${ }^{86}$ Kant thus does not simply assert value as attaching to a particular category but identifies the capacity for rational agency as the ground of worth or dignity that in turn provides the justification for according a special status and treatment to humanity. The Kantian view on dignity has been influential in South African judgments ${ }^{87}$ as well as legal writing ${ }^{88}$ and could perhaps provide some explanation for the exclusion of animals from being recognised as natural persons and having 'dignity' in their own right.

Yet, the Kantian view on dignity is perhaps one of the least justifiable elements of his moral system and can be subjected to a number of damaging criticisms. First, we require an independent argument for the claim to be accepted that worth or dignity lies in rational agency alone and that rational nature is the only thing that exists as an end in itself. Kant's claim that '[t]he human being necessarily represents his own existence in this way ${ }^{89}$ may be true for most human beings: ${ }^{90}$ it may also be true that all rational beings must necessarily regard their existence in this way. ${ }^{91}$ Nevertheless, it does not follow from the fact that we represent our existence to ourselves in a particular way that others ought to treat us in accordance with our own subjective representations. ${ }^{92}$ Furthermore, the fact that rational beings may regard themselves as

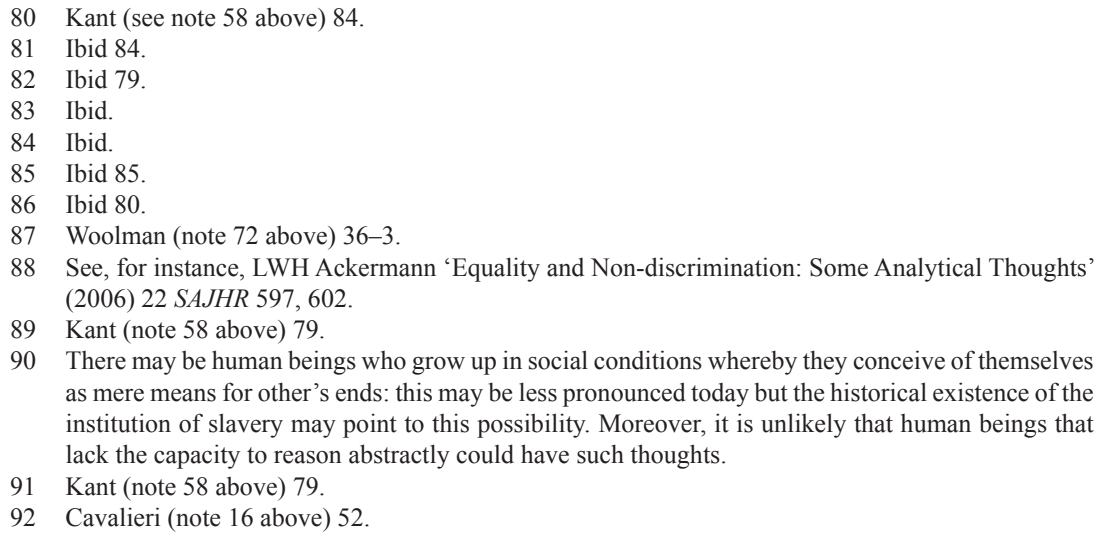

90 There may be human beings who grow up in social conditions whereby they conceive of themselves as mere means for other's ends: this may be less pronounced today but the historical existence of the institution of slavery may point to this possibility. Moreover, it is unlikely that human beings that lack the capacity to reason abstractly could have such thoughts.

91 Kant (note 58 above) 79.

92 Cavalieri (note 16 above) 52. 
being ends-in-themselves provides no justification for concluding that it is only rational beings that ought to be treated as ends in themselves: it may be that there are other grounds upon which non-rational beings ought to be treated in this way. ${ }^{93}$

A second important argument to consider in this context is that, even if we accept that rational agency is of value, it is not self-evident that it is an all-ornothing characteristic. This concept seems to embrace a wide range of mental phenomena, some of which may be possessed by animals. ${ }^{94}$ First, instrumental rationality refers to means-end reasoning of the following type: '[i]f we want $\mathrm{X}$ and realize that by doing $\mathrm{Y}$ we can get $\mathrm{X}$, and act accordingly, then our behaviour is rational'. ${ }^{95}$ This type of reasoning is strongly connected to our ability to have desires and beliefs and act in ways that realise such desires and beliefs. Thus, a dog that is hungry and goes to its bowl where food is usually given to it demonstrates such a form of instrumental rationality. There is strong evidence that many animals are capable of such forms of rationality. ${ }^{96}$

Secondly, there are forms of rational behaviour that require some degree of learning, innovation and flexibility. ${ }^{97}$ If we block off the easiest access route to the dog's bowl where there are several and find that the dog is able to find another route to the bowl, then the dog's behaviour demonstrates some ability to reason concerning the best method of achieving its goal. Such forms of behaviour are also common amongst mammals. ${ }^{98}$

Thirdly, moral altruism is a more sophisticated form of behaviour that may be reflected in actions that display some form of concern for others even if they are largely instinctual or conditioned. ${ }^{99}$ Some animals frequently display forms of such behaviour where, for instance, orphans are adopted by other members of a group or where healthy animals care for old or feeble companions. ${ }^{100}$ Finally, there are yet more sophisticated forms of behaviour that involve full-fledged moral agency ${ }^{101}$ - where agents deliberate on the basis of moral reasons, and act on the basis of that deliberation - and full autonomy ${ }^{102}$ - which involves evaluating one's action-guiding preferences, understanding their influence on one's behaviour and deciding how to act accordingly. As far

C Hoff 'The Moral Domain: An Inquiry into Its Extent and Limits' referred to in P Cavalieri (note 16 above) 53 .

94 This paragraph covers a range of concepts in philosophy of mind all of which could be the subject of further analysis. The point is simply to indicate the range of mental phenomena that may be classed under the notion of rational agency and to recognise that non-human animals possess some of these characteristics

95 J Rachels Created by Animals: the Moral Implications of Darwinism (1990) 140.

96 DeGrazia (note 48 above) 136 and 158-65.

97 Ibid 164

98 Ibid 165.

99 Ibid 199

100 Rachels (note 95 above) 148.

101 DeGrazia (note 48 above) 203

102 Ibid 207. 
as we know, few if any animals possess such capacities. ${ }^{103}$ The important point is that rational agency falls on a continuum and that many forms of human rational behaviour have analogues in the animal kingdom. ${ }^{104}$ If rational agency is the criterion for worth, and we recognise the fact that a number of animals possess certain forms of rational agency to various degrees, then we must recognise that at least some animals should have worth (at least in proportion to their possession of such agency). ${ }^{105}$

A Kantian, however, may be unmoved by these considerations and argue that what matters for dignity is ultimately sophisticated mental capacities involved in full moral agency or full autonomy. ${ }^{106}$ However, perhaps the most important objection against this view (and others that identify sophisticated mental capacities as the criterion of value) is that the capacity for such sophisticated forms of agency is not possessed universally by all human beings: young children, the senile and persons with mental incapacities may not possess moral agency or full autonomy: does this entail their lives lack worth or dignity? It seems clear that we should not be able to treat human beings as lacking worth and purely as a means to our own ends simply because they lack the sophisticated capacities for full autonomy. However, if we are required to treat all human beings as having worth and with respect even where they lack full autonomy, then it seems that full autonomy cannot be the sole ground upon which we determine the worth and treatment of a being. It is some other characteristic that must ground dignity and the requirement to treat them accordingly. If this is so, however, and the characteristic is shared by at least some animals, then such animals also must be recognised as having value and treated in accordance with their worth.

\section{(c) The argument from marginal cases}

This argument may be referred to as the 'argument from marginal cases' and has been influential in extending justice beyond the human species. ${ }^{107}$ In a

103 DeGrazia (note 48 above) provides a careful analysis of the various mental states that may be attributed to non-human animals. A proponent of the view discussed in the text must identify certain characteristics possessed only by humans. DeGrazia's analysis suggests that such characteristics are more limited than we ordinarily assume but would probably include 'full-fledged moral agency' and full autonomy referred to above (203-10).

104 Steven M Wise Rattling the Cage: Towards Legal Rights for Animals (2000) 246-7 distinguishes between 'full autonomy' in the Kantian sense and 'realistic autonomy' which involves having preferences and the ability to act to satisfy them; being able to cope with changed circumstances; having desires and beliefs and being able to make some sound inferences from them and the like.

105 Alan Gewirth whose theory of rights is Kantian in character recognises that non-human animals may have rights in proportion to their capacity for agency or to their possession of the shared capacities that underlie agency. See A Gewirth Reason and Morality (1981) 144.

106 For ease of use, I refer to 'full autonomy' as the characteristic in question in the following discussion.

107 P Singer (note 48 above) 16-20 and P Cavalieri (note 16 above) 76. For what I regard as an ultimately unsuccessful critique, see E Anderson 'Animal Rights and the Values of Nonhuman Life' in CR Sunstein \& MC Nussbaum (eds) Animal Rights: Current Debates and New Directions (2004) 277. 
more formal way, the general form of this argument can be characterised as follows:

(1) All and only beings which have a particular characteristic X (for example, full autonomy) have worth and impose duties of justice upon us to respect, protect, promote and fulfil their fundamental rights; ${ }^{108}$

(2) Some human beings (for example, infants or those with severe mental disabilities which shall be termed 'non-paradigm human beings') do not have characteristic $\mathrm{X}^{109}$

Therefore,

(3) Some human beings do not have worth and there are no duties of justice upon us to respect, protect, promote and fulfil their fundamental rights, ${ }^{110}$

(4) However, we are committed to the moral proposition that all human beings have worth and that we have duties of justice to respect, protect, promote and fulfil their fundamental rights;

(5) If we wish to defend proposition (4) without resorting to speciesism, characteristic X cannot be the correct basis for determining the worth of a being or for imposing duties of justice upon us to respect, protect, promote and fulfil fundamental rights;

(6) However, any characteristic $Y$ that will include all human beings as having worth (and will impose duties of justice upon us) will also be possessed by some non-human animals. ${ }^{111}$

Therefore,

(7) At least some non-human animals have worth and are owed duties of justice to respect, protect, promote and fulfil their fundamental rights.

The more complex the feature of value (characteristic X) is in the above argument, the more human beings are excluded from having worth. However, a fixed point in the moral judgments of most human beings is that they wish all humans to be regarded as being of worth who we owe duties of justice. The alternative is to allow infants or mentally disabled human beings to be treated as 'things' without any fundamental rights. This would imply we could use

108 This first premise could be formulated in many ways but I have formulated it in accordance with the current context that relates to the imposition of duties of justice arising from fundamental rights that relate to the worth of a being.

109 For an interesting account of the abilities and capacities of profoundly intellectually disabled humans as compared with those of the great apes see the article of a Professor of Special Education at the University of Dortmund Christoph Anstotz in P Cavalier \& P Singer (eds) The Great Ape Project (1993) 158-72.

110 Numerous general terms have been placed in the above argument - which can be filled out in many different ways. The notion of 'worth' and 'fundamental rights' could be substituted by the notion of having 'moral standing' or 'having interests which deserve moral consideration', or 'are persons'. Arguments as to why animals should count morally are canvassed extensively in KA Horsthemke The Moral Status of Animals (1993), an unpublished Doctoral thesis, University of the Witwatersrand. T Regan (note 16 above) applies the above argument in order to make a case for animal rights and P Singer (note 48 above) 160 uses it to make an argument for the equal consideration of animal interests.

111 This is an empirical claim but, as has been pointed out above and in footnotes relating to the mental lives of animals, it is true. 
them in painful medical experiments if we wished or kill them should this be expedient. Such views are generally seen to be morally repugnant and led, for instance, at the time of Nazi Germany to the murder of many of the mentally ill. However, if we want to claim that all human beings - including infants and the mentally disabled - have worth, characteristics have to be found which are common to all human beings. This means, however, that relatively simple mental capacities - such as sentience - will be required for a human being to be regarded as having worth. Since such capacities are also present in many animals, the conclusion of the argument must then be that those animals which have these capacities must also be regarded as having worth and treated accordingly.

Many philosophers do not wish to give up their belief that 'characteristic $X^{\prime}$ that determines worth should include sophisticated capacities such as the ability to be a fully autonomous entity, and the like. Yet, they wish to exclude animals from having worth but include non-paradigm human beings. ${ }^{12}$ I shall now briefly outline three common attempts to do so, all of which I shall argue are unsuccessful.

\section{(i) Using the paradigm human cases to include the non-paradigm}

First, John Finnis argues that what distinguishes human beings from animals is the fact that the human good involves an extensive and wide range of pursuits. Even the bodily human goods are experienced, he claims, as 'expressive of decision, choice, reflectiveness, commitment, as fruition of purpose, or of selfdiscipline or self-abandonment and as the action of a responsible personality'. ${ }^{113}$ The obvious objection to this line of reasoning is that non-paradigm humans do not have such an extensive form of the good which, in some cases, may be a less sophisticated form of the good than a clever, friendly and flourishing dog could experience. In reply, Finnis claims that 'respect for the human good reasonably extends as far as [the] (sic) human being, and is not to be extinguished by the circumstance that the incidents or "accidents" of affairs have deprived a particular human being of the opportunity of a full flourishing, ${ }^{114}$ Finnis thus argues that the general capacity of human beings to experience the full human good should be sufficient to confer worth even upon those human beings who lack such a capacity.

It would seem that an air of desperation attaches to this reasoning. It is difficult to see why the claim that the human good reasonably extends as far as the human being is not merely an empty tautology or a naked, arbitrary preference for the human species. What non-paradigm human beings do is place in question whether the so-called 'human good' which Finnis defines in terms of fairly lofty ideals and complex characteristics is really the good for all human beings. If it is not, then it makes no difference how this situation 
arose: through an unnatural 'accident' or part of the ordinary course of nature. Such an individual would not be fully human according to Finnis and thus it is difficult to see why she should be accorded the same status or respect as other 'fully flourishing' human beings. ${ }^{115}$ Similarly, Cavalieri provides a telling example to highlight the inadequacy of this reasoning. Imagine that we discovered that women in general are less gifted than men for a particular job such as mechanical engineering. However, certain particular individual women are more gifted than some particular men at mechanical engineering. It is implausible and unfair to argue that 'men endowed with lesser capacities were given preference over those women for jobs requiring the level of capacities they actually have, on the ground that women and men should be treated not according to their actual characteristics, but to what is typical of their "kind"".

\section{(ii) Partial autonomy?}

Mary Anne Warren makes the second attempt to differentiate the worth of non-paradigmatic humans from animals. ${ }^{117}$ She accepts that if potential autonomy is a reason for granting infants full moral rights, then even 'ununited human sperm-egg pairs would have to be regarded as entities with a right to life the equivalent of our own'. ${ }^{118}$ She claims, however, that infants and children possess not only potential but partial autonomy. Since they will probably become fully autonomous, she argues that it is likely that their minds have more subtleties than they can express through speech at a particular moment in time.

The fact, however, that one may become fully autonomous in no way implies that at any given moment after birth one has even partial autonomy. An infant has various potential abilities or dispositions - for instance, to learn language - which are gradually unlocked at various stages of its development. There is no reason to believe that before such a developmental stage is reached the infant really has those abilities even in a partial way. Thus, once a child begins to utter its first words, we can speak of the partial acquisition of language; prior to this, however, it is simply an incorrect description to claim that

115 M Leahy 'Brute Equivocation' in M Leahy \& D Cohn-Sherbok (eds) The Liberation Debate (1996) 194 raises an argument similar to that of Finnis - 'that the normal generality of homo sapiens is unequivocally demarcated from brutes would seem to justify according a form of honorary status to those people enfeebled through age or retardation'. I find it difficult to understand why the greater capacities of some human beings should provide a reason to regard others as if they had those capacities where they do not in fact have them. Furthermore, mysteries abound when we begin to think in this way - is a foetus to be regarded as an 'honorary homo sapien' due to the status of the normal generality of homo sapiens? Would every sperm be sacred?

116 Cavalieri (note 16 above) 74 .

117 See MA Warren 'The Rights of the Nonhuman World' in R Elliot \& A Gare (eds) Environmental Philosophy: A Collection of Readings (1983). She does not deny that animals have 'moral rights' but rather wishes to accord them 'less rights' than other human beings (both paradigm and nonparadigm). For her more comprehensive and sophisticated account, see MA Warren Moral Status (1997).

118 Ibid 121 
an infant has the ability to use language even partially. Similarly, an infant of six weeks develops the ability to act fully autonomously only much later in its life. Though it may have certain dispositions eventually to develop such full autonomy, those dispositions remain underdeveloped until a much later age. It is simply a misleading description to suggest that the infant possesses some form of 'partial autonomy'.

\section{(iii) Our social programming}

However, Warren's main argument - the third objection we shall consider - relates to the fact that other human beings with fully developed capacities tend to place a very high value on the lives and well-being of infants and the mentally handicapped.

Perhaps we are to some degree 'programmed' by nature to love and protect them; perhaps our reasons are somewhat egocentric; or perhaps we value them for their potential. Whatever the explanation, the fact that we do feel this way about them is in itself a valid reason for extending to them stronger moral and legal protections than we extend to nonhuman animals, even those which may have just as well or better developed psychological capacities. ${ }^{119}$

This appears to be a form of relational argument which considers the particular social bonds we have to other human beings. ${ }^{120}$ Yet, when considering the worth of an individual and their fundamental rights one is on extremely shaky ground where one's only basis for differential treatment lies in one's 'natural' feelings towards members of one's own species. Many people still feel a 'natural' solidarity with others of the same race and place a low value on the well-being of those who differ racially from them. Similarly, many others consider women to be inferior, value them only for their child-bearing potential and conclude that women should not be accorded full legal rights in the public political sphere. ${ }^{121}$ Strong feelings such as these can merely mask unjustifiable prejudice. ${ }^{122}$ Consider a situation where there exists a certain class of infants who no one in society cares for or values. ${ }^{123}$ Would it be correct to treat them any differently to another class of infants who most people regard as highly valuable - particularly in relation to their fundamental rights - where there is no difference in their respective abilities or capacities?

\section{(d) Dignity and difference}

The unsuccessful attempts to rebut the argument from marginal cases demonstrates that dignity and fundamental rights are not dependent upon the

119 Ibid 121.

120 Elizabeth Anderson (note 107 above) makes a similar argument yet with some interesting nuances: a full reply to some of these complexities lies beyond the scope of this article.

121 The religious laws of Islam and Judaism, for instance, seem to protect women in the private sphere but grant them few rights to develop their capacities for rationality and leadership in the public sphere.

122 Cavalieri (note 16 above) 80.

123 This could be made less hypothetical by considering whether Hutus may justifiably treat Tutsi infants as being of lesser value based on their feelings of solidarity with other Hutus alone. 
presence of sophisticated mental capacities such as 'rational agency'. If nonparadigm human beings are to be regarded as having dignity despite their having limited mental capacities, then so too should certain animals have dignity. Similarly, if fundamental rights are accorded to non-paradigm human beings and there are no relevant differences between such human beings and certain animals, then there appears to be no non-arbitrary reason to deny that those animals can also have such fundamental rights. ${ }^{124}$

Nevertheless, there is something I feel which the argument from nonparadigm human cases simply does not capture. This is brought out by an example from feminist writings in connection with maternity rights. In order to justify granting women special treatment due to their pregnancy, courts in a number of cases sought to find a male comparator that would qualify for similar treatment. They thus sought to compare pregnant women to men with a medical condition, that would require the man in question be absent from work for the same period of time as the pregnant woman. ${ }^{125}$ Yet, pregnancy is not an illness but rather a natural process that many women choose to undergo in order to produce children. ${ }^{126} \mathrm{~A}$ basis needed to be created for attributing maternity rights to women in the absence of a male comparator.

Similarly, the argument from marginal cases compares non-paradigm human beings to non-human animals. Yet, a fully developed functioning animal is not mentally defective in any way; neither is it immature. For its species, it is a fully developed normal specimen. A child on the other hand is a young human being whose capacities are not yet fully developed; a mentally handicapped human being, on the other hand, lacks certain capacities completely which will never be developed. ${ }^{127}$ Mackinnon cleverly outlines the problems with such comparators in exploring the similarities between the treatment of women and animals. She states that the problem is

why animals should have to be like people to be let alone by them, to be free of the predations and exploitations and atrocities people inflict on them, or to be protected from them. Animals don't exist for humans any more than women exist for men. Why should animals have to measure up to human's standards for humanity before their existence counts? ${ }^{128}$

Whilst the similarities between non-paradigm humans and animals are significant for displaying inconsistencies in our moral and legal frameworks, it is important that we should be able to consider that a being has 'dignity' or 'value' or that its fundamental rights should be respected without having to establish that one particular kind of being is like another. I shall argue in the next section that the capabilities approach as recently developed by Martha Nussbaum in her book Frontiers of Justice is able to embrace these concerns

124 J Rachels 'A Reply to VanDeVeer' in T Regan \& P Singer (eds) Animal Rights and Human Obligations (1976) 230.

125 See for instance Webb v EMO Air Cargo (UK) Ltd (1992) 2 All ER 43.

$126 \mathrm{~J}$ Kentridge 'Measure for Measure: Weighing up the Cost of a Feminist Standard of Equality at Work' in C Murray (ed) Gender and the New South African Legal Order (1996) 84.

127 See also M Nussbaum Frontiers of Justice (2006) 363-4.

128 C MacKinnon 'Of Mice and Men: A Feminist Fragment on Animal Rights' in CR Sunstein \& MC Nussbaum (eds) Animal Rights: Current Debates and New Directions (2004) 267. 
and enables us to develop a conception of dignity that can embrace the full range of creatures that have value and which will require that we respect their rights. Some of the implications of this revised conception of dignity for the South African law relating to animals are then discussed.

\section{Taking the Law Beyond Arbitrariness: Recognising the Dignity And Personhood of Animals}

\section{(a) The dignity of animals}

The alternative conception of dignity that I shall consider is rooted in a theory of value known as the capabilities approach, the most famous proponents of which are Amartya Sen and Martha Nussbaum. According to this view, value in an individual life is to be understood in terms of functionings and capabilities.

Sen characterises functionings as representing "parts of the state of a person - in particular the various things that he or she manages to do or be in leading a life'. ${ }^{29}$ This is a very broad notion and includes passive states of the individual such as being well-nourished and being healthy, as well as activities that an individual engages in such as playing soccer or playing the piano. Capabilities, on the other hand, represent sets of alternative combinations of functionings that an individual can attain. ${ }^{130}$ The concept recognises that there are alternative courses an individual's life may take, and that the choice between these courses is an important value for those capable of such a choice. The notion of a capability also recognises that the achievement of functionings is limited by a number of factors, including individual abilities, the resources at an individual's disposal and the existence of social, environmental and physical constraints.

For Sen, the life of an individual is to be seen 'as a combination of various "doings and beings", with the quality of life to be assessed in terms of the capability to achieve valuable functionings'. ${ }^{131}$ The central question of the capabilities approach is thus whether a person is capable of being or doing X. However, put in this way, the central incompleteness of Sen's approach can clearly be seen as it is simply incorrect to assert that all states of being and doing enhance our lives. ${ }^{132}$ We need some basis upon which to judge which capabilities are important to us, and whether there are different degrees of importance amongst capabilities. ${ }^{133}$

Initially, Nussbaum attempted to resolve this problem by providing an account of what are valuable functionings and capabilities for fully function-

129 A Sen 'Capability and Well-Being' in A Sen \& M Nussbaum (eds) The Quality of Life (1993) 31.

130 A Sen Inequality Re-examined (1992) 40.

131 Sen (note 129 above ) 31.

132 Some functionings have a minor impact on our lives whilst others may have a negative value and detract from our ability to live well: see B Williams 'Interests and Capabilities' in G Hawthorn The Standard of Living (1985) 98.

133 Ibid 100. 
ing adult human beings. ${ }^{134}$ However, in her recent book Frontiers of Justice, ${ }^{135}$ she has sought to show how the capabilities approach can also provide such an account for mentally and physically disabled humans as well as animals.

Nussbaum contends that the basic moral intuition of the capabilities approach concerns 'the dignity of a form of life that possesses both abilities and deep needs. Its basic goal is to address the need for a rich plurality of life activities'. ${ }^{136}$ Value for Nussbaum lies in capabilities and it is not simply human capabilities that count: 'it is good for ... a being to persist and flourish as the kind of thing it is. This idea is at least closely related to an ethical judgment that it is wrong when the flourishing of a creature is blocked by the harmful agency of another'. ${ }^{137}$ Nussbaum recognises that there are many types of creatures that are the subjects of justice, each 'striving to live their lives, each life with its dignity'. ${ }^{138}$ Flourishing can take various forms and different beings have different forms of the good: what is important is that they are able to exercise and develop their unique capabilities that are particularly good for the kind of creatures they are. The value of particular functionings and capabilities are thus determined according to what enables individual creatures to flourish as the kind of being that it is.

The core of the capabilities approach is thus based upon the idea that 'animals are entitled to a wide range of capabilities to functions, those that are most essential to a flourishing life, a life worthy of the dignity of each creature'. ${ }^{139}$ The exact entitlements of individuals will depend upon their characteristic forms of life and flourishing: nevertheless, Nussbaum develops a list of central capabilities that determine broadly the entitlements of various creatures. The list is fairly extensive and ranges from an entitlement to bodily health and integrity, to adequate space, light and sensory stimulation, respect for territorial integrity to respect for the emotions and social lives of individuals. ${ }^{140}$

Many of the philosophical approaches that have sought to extend protections to animals have focused upon the notion that animals have a subjective consciousness - are 'sentient' - and their lives can thus go better or worse for them. Sentience still remains a precondition for having capabilities and thus worth in Nussbaum's theory. ${ }^{141}$ Yet, a virtue of her account is the recognition that the good for different creatures is plural and diverse and cannot be reduced necessarily to one type of mental state such as pleasure: '[a]nimals, like humans pursue a plurality of diverse goods: friendship and affiliation, freedom from pain, mobility

134 See M Nussbaum Women and Human Development (2000) 73-4 for a critique of her efforts; D Bilchitz Poverty and Fundamental Rights (2008) 14-5. See also L Antony 'Nature and Norms' (2000) 111 Ethics 8, 34.

135 Nussbaum (note 127 above).

136 Ibid 346.

137 Ibid 349 .

138 Ibid 356.

139 Ibid 392.

140 Ibid 393-400.

141 Ibid 362 ('[s]entience is not the only thing that matters for basic justice; but it seems plausible to consider the possession of sentience as a threshold condition for membership in the community of beings who have entitlements based on justice'). 
and many others, ${ }^{142}$ Value rests in the many varied capabilities and functionings of sentient creatures. This expanded concept of dignity thus confers worth on all creatures which are capable of leading good lives and requires that we treat all such creatures in accordance with that worth. This means that we owe at least animals who have the capacity to flourish - including mammals, reptiles and birds - direct duties of justice which entail that must we respect, protect, promote and fulfil their fundamental entitlements. ${ }^{143}$

Nussbaum's notion of dignity and capabilities is attractive in that it inculcates respect for each form of life that exists and requires us to treat each being according to standards appropriate for its flourishing. This means that we do not automatically judge any particular species as having less worth than any other and we respect each individual for the kind of being that it is. The problem with this view arises in cases of conflict between individuals of different species: for instance, if we have within our care a chimpanzee and a lizard and we only have the capacity to save one, which creature should we save?

Nussbaum explicitly recognises this problem and her view does enable us to make morally relevant distinctions between different forms of life where it is necessary to do so. On the capabilities view, however, it is important how we think through such cases. 'Level of life is relevant not because it gives different species differential worth per se, but because the type and degree of harm a creature can suffer varies with its form of life, ${ }^{144}$ This allows us to recognise that ' $[\mathrm{m}]$ ore complex forms of life have more and more complex (good) capabilities to be blighted, so they can suffer more and different types of harm, ${ }^{145}$ If we are seeking to minimise harm, and we are faced with an unavoidable conflict, we would generally be required to harm or sacrifice the creature with the lesser cognitive complexity (which often tracks the range of capabilities that a creature may have). ${ }^{146}$ Importantly though, these judgments will not always track the species barrier and they will be dependant upon the capabilities of the individuals

142 Ibid 344.

143 This does not, however, mean that we owe them identical duties to that which we owe other humans. See below for further discussion.

144 Nussbaum (note 127 above) 361.

145 Ibid.

146 Whilst it may be relatively simple to judge the differences in capabilities between a lizard and chimpanzee, these judgments may become increasingly difficult the more similar two creatures are. Given that flourishing for simpler creatures does not lie in the exercise of complex capabilities, it may be wondered how we can judge that lesser harm is done to them if they are allowed to die (or be killed) simply because they have less complex capabilities. This suggests an ambiguity in the capability view: does value lie in the capacity of a creature to flourish on its own terms or in the capabilities themselves? Nussbaum seems to suggest that value lies in capabilities and the more complex and varied the capabilities a creature has, the more likely it is to take priority over a creature with lesser and simpler capabilities. Yet, this seems to 'fetishize' capabilities as being valuable for their own sake and contradicts the very way in which we determine which capabilities are valuable in Nussbaum's view (which is through their capacity to contribute to the flourishing of creatures). To deal adequately with conflicts between species, her view may need to be supplemented with an account of why certain forms of flourishing (involving the exercise of more complex capabilities) can be judged to involve greater degrees of value than other forms. This will require a more detailed account of value as well as the development of an inter-species theory of value. For an attempt to consider some of the interesting issues that arise in this regard, see DeGrazia (note 48 above) 211-57. A fuller discussion of these issues lies beyond the scope of this article. 
concerned: faced with a conflict between a terminally ill, deranged chimpanzee and a healthy cat, we may be required to save the cat in this instance (if we are forced to choose) despite chimpanzees as a whole generally having more complex and varied capabilities than those of cats.

The capabilities view would, however, focus on attempting to reduce the conflict between species and minimise the harm that occurs when such conflicts do arise. ${ }^{147}$ It is important to recognise that tragic conflicts may arise, at times, between human beings with a doctor only having enough medicine to save either a 20 -year-old or a 90-year-old. Whilst we may have good reasons - without other information - for saving the 20-year-old who still has the opportunity to live a life ahead of her, this does not mean that we do not respect the dignity of the 90 -year-old or generally devalue the lives of elderly people. In a similar way, recognising that in cases of conflict, members of species with lesser degrees of cognitive complexity may lose out to those with higher degrees of complexity does not mean that, as a general rule, we do not respect the dignity of the species with lesser degrees of complexity or generally devalue their lives.

There is something peculiarly appropriate about using Nussbaum's theory to inform legal developments in South Africa. It attempts to move away from arbitrary exclusions (something that has characterised South Africa's past) to embrace all beings capable of flourishing. It also seeks to respect the variable goods of different beings, reflecting the distinctiveness and individuality of each. The last sections of this article seek to consider the implications of embracing such a revised conception of worth for South African law.

\section{(b) Towards legal personhood for animals?}

I have argued in this article that the existing concept of the person in South African law is clearly not restricted only to those capable of having both rights and duties but embraces all those capable of having either rights or duties. If animals are capable of having legal rights, then conceptually, they may be recognised as natural persons. Yet, our law currently restricts the class of natural persons to all and only human beings. I have sought to investigate possible rationales for such a restriction, focusing particularly on claims concerning the fact that the notion of 'human dignity' provides such a justification. It has been argued that there is no justifiable basis upon which to restrict worth (and fundamental rights) to all and only human beings. An alternative conception of dignity was then outlined that was capable of justifying the attribution of worth (and fundamental rights) both to humans and many other animals. Without any adequate justification for regarding animals as 'things', the conclusion must then be that that at least some animals (with the capacity to flourish) must be included within the class of natural persons in South African law. ${ }^{14}$

147 Nussbaum (note 127 above) 401-5.

148 Clearly, this change in classification is not an end in itself: it is the implications of such a change in status that matters. Recognition of the personhood of non-human animals must be conjoined with a recognition and protection of fundamental rights for animals. For a more sceptical view, see JR Lovvorn 'Animal Law in Action: the Law, Public Perception and the Limits of Animal Rights Theory as a Basis for Legal Reform' (2005) 12 Animal Law 133, 143. 
The notion that a being with a welfare is classified in the same category as bricks, mortar and land (with the attendant consequences) has always been anomalous in South African law. Prior to 1993, South African law was replete with arbitrariness between black and white people, men and women. It is not surprising therefore that the law arbitrarily distinguished between the human and the non-human in terms of their legal status and entitlements. ${ }^{149}$ Arbitrariness, whilst undesirable in itself, also often leads to the disregarding of the interests of individuals, often those who are most vulnerable. However, the new constitutional order was to be formed on the basis of a rejection of arbitrariness and the protection of the fundamental interests of all (particularly those who are most vulnerable) $:^{150}$ what then should this entail for animals?

Clearly, the most desirable route would involve a constitutional amendment, whereby the rights of animals would be explicitly protected directly through the Constitution. This is a route that has been followed in Switzerland where in 2000, recognition of the 'dignity of creatures' was placed in its Constitution. ${ }^{151}$ In 2002, Germany amended its basic law to include recognition of animal interests and our duty to protect them. ${ }^{152}$ Absent from the South African Constitution are any express provisions providing for the rights of animals. ${ }^{153}$ Indeed, the only express protections that may cover animals could be $\mathrm{s} 24$ which protects certain environmental rights including the right to have the environment protected for the benefit of present and future generations and includes reference to conservation and sustainable development. ${ }^{154}$

149 The irrationality of classifying animals as things was recognised even prior to the advent of the new constitutional order by certain far-sighted authors: Labuschagne (note 27 above) $340-1$, for instance states that '[d]ie bewering wat dikwels gemaak word dat 'n dier nie regsubjektiwiteit kan hê nie, is niks anders as 'n voor-analitiese postulering van 'n analitiese resultaat nie; dit is 'n vooruitgedateerde konklusie en moet as onwetenskaplik bewerp word. So 'n benadering is gebaseer op 'n oordrewe antroposentristiese spesisisme wat nie verband hou met die regswerklikheid nie'.

150 See notes 2-6 above and references therein.

151 Section 24 of the Swiss Constitution. See KM Nattrass “ “... Und die Tiere” Constitutional Protection for Germany's Animals' (2004) 10 Animal Law 283.

152 See Grundgesetz Article 20a: '[m]indful also of its responsibility toward future generations, the state shall protect the natural foundations of life and animals by legislation and, in accordance with law and justice, by executive and judicial action, all within the framework of the constitutional order' (translation by Sebastian Seedorf). The recognition, however, is not adequate as it fails to grant rights to animals and simply places animal interests as a value and goal to be taken into account by the State - something, that would nevertheless be progressive in South Africa where animal interests are often disregarded. See Nattrass ibid for a discussion as to its history and implications some of which are relevant to South Africa.

153 Interestingly, in his famous 'I am an African' speech, President Mbeki recognised that we shared the land with other creatures and wondered whether he should concede equal citizenship of our country to the animals of South Africa. 'At times, and in fear, I have wondered whether I should concede equal citizenship of our country to the leopard and the lion, the elephant and the springbok, the hyena, the black mamba and the pestilential mosquito', <http://www.nathanielturner.com/iamanafrican.htm>. Most members of Parliament laughed at the suggestion despite strong public written submissions supporting the recognition of such rights.

154 Section 24 reads as follows: 'Everyone has the right (a) to an environment that is not harmful to their health or well-being; and (b) to have the environment protected, for the benefit of present and future generations, through reasonable legislative and other measures that (i) prevent pollution and ecological degradation; (ii) promote conservation; and (iii) secure ecologically sustainable development and use of natural resources while promoting justifiable economic and social development'. 
However, this right does not expressly refer to animals and no distinction is made between such creatures and plants, stones or rivers. Classing sentient animals as simply part of the environment allows such creatures to be treated merely as 'things' without interests of their own. Thus, it may make sense to talk of the 'use' of natural resources such as timber or water, but this framework is woefully inadequate when applied to animals with interests of their own. Their interests require careful consideration in their own right and should be a critical factor in any decision-making that affects them.

Yet, in the absence of a constitutional amendment (which seems unlikely), our Constitution can in fact convincingly be interpreted to recognise the dignity and interests of animals. The application clause of the Bill of Rights is most crucial: to whom does the Bill of Rights offer protection? In answering this question, it is interesting to note that it points to a gap in the constitutional text. Section 8(4) provides that '[a] juristic person is entitled to the rights in the Bill of Rights to the extent required by the nature of the rights and the nature of the juristic person'. Thus, the Constitution provides expressly for the rights of juristic persons yet there is no similar provision in relation to natural persons. It would be absurd, however, to suggest that the Bill of Rights was only designed to protect the interests of juristic persons and there are other clear textual pointers against such an interpretation. ${ }^{155}$ Perhaps it was too obvious to include in the application clause but the rights of natural persons must, by necessary implication, be protected by the Bill of Rights. The extension of the category of natural persons thus becomes crucial in determining who is entitled to the protection of the Bill of Rights. I have already argued why it is unjustifiable to exclude animals from this category and, indeed, the very argument I have presented could find support from the fundamental value of equality in our Constitution which eschews arbitrary distinctions between categories of beings. Whilst the Constitution specifically refers to 'human dignity', it does not exclude the possibility that the law can recognise the dignity of other types of beings. It would thus not preclude recognition of animals as 'natural persons'.

Another approach also would be viable in terms of our constitutional framework. For if an artificial legal fiction such as a company can be entitled to protections under the Bill of Rights, then a fortiori, it appears that sentient beings who have fundamental interests that can affect their very capacity

155 Indeed, s 7(1) of the Constitution provides that the Bill of Rights 'enshrines the rights of all people in our country and affirms the democratic values of human dignity, equality and freedom'. This section could be said to cause trouble for the interpretation I provide by referring to 'people': yet, again, that begs the question as to who is included within the category of 'persons'.

156 Indeed, the explicit textual focus on human dignity can be explained through understanding that the South African Constitution was passed specifically to repudiate the massive denials of the dignity of black people that occurred during apartheid and to signal that, in future, all human beings would be treated as being of equal value: See Woolman (note 72 above) 2-4. Against this historical backdrop, it does not seem that the focus on 'human dignity' in the Constitution sought specifically to consider the question of whether dignity extends beyond the human species or specifically to exclude nonhuman animals from having dignity. Consequently, given the good reasons for recognising that animals too have dignity, and the arbitrariness of excluding animals from the category of natural persons, it does not appear that the Constitution itself has created any insuperable barrier to the legal advances advocated in the text. 
to flourish and live lives of value by their own lights, should be entitled to such rights. Indeed, reasoning such as this has led to the suggestion by some authors that animals be classified as a particular type of 'juristic person' rather than a 'natural person'. ${ }^{157}$ Since the law may confer legal personality on any entity that it wishes, and there is a strong claim on the part of animals to be protected by law in their own right, this may offer a solution that would extend legal personality to animals with only a minimal shift in the traditional meaning of the notion of 'natural personality' in our law. This taxonomy does not, however, strike me as ideal as it makes more sense to place similar entities in the same category: since humans and animals are both natural entities with intrinsic value in their lives and a welfare of their own, they belong in the same category and should be considered 'natural persons'. Unlike companies where legal personality is in fact a fiction, in the case of both animals and humans, it results from their very natures as beings with worth in their own right.

Whichever approach is adopted, however, it is important to consider the content of s 8(4) which provides that the rights of a company may vary with the nature of the entity concerned: thus a company may need certain rights to privacy or to property but it cannot really have a right not to be tortured or the right to vote. Though there is no similar provision applying to natural persons, it is clear that such a provision must be inferred: whilst infants may have a right to freedom and security of the person, they cannot claim political rights (which are meaningless to them), or rights such as freedom of religion and freedom of trade and occupation given their lack of capacity to exercise such rights. Recognition of this point is crucial in that it importantly allows for the nature of the fundamental rights of natural persons to vary depending upon the capabilities of such a person. ${ }^{158}$ In the same way that infants do not have the right to vote, it would be meaningless for a chimpanzee to be granted such a right. ${ }^{159}$ However, the right to be free from all forms of violence, and not to be tortured, are critically important both for infants and for a chimpanzee: these are often referred to as rights to bodily integrity. Animals may also require certain rights to live in a habitat appropriate to their needs (a variant of the right to property), the right not to be deprived of the means of living (certain socio-economic rights), and the autonomy to live lives that are good in their own terms without undue human interference (certain freedom rights would thus be applicable to them). Once we recognise that animals cannot justifiably be excluded from the legal category of being persons (and rights-holders), it then becomes possible to recognise that they are already entitled to many of the protections included in the Bill of Rights.

157 See, for instance, D Favre 'A New Property Status for Animals' in Sunstein \& Nussbaum (note 128 above) $244-5$.

158 It also demonstrates the insights that can be garnered by applying the capabilities approach to the fundamental rights in the Constitution.

159 There is simply no interest in these beings having the right to vote and consequently there is no right: 'nothing is blighted when a rabbit is deprived of the right to vote, or a worm of the free exercise of religion' (Nussbaum (note 127 above) 361). 


\section{(c) Towards the 'progressive realisation' of animal rights in South Africa}

Of course, even the most rudimentary protection of animal rights would require wide-ranging changes to human practices. Recognising that animals have worth in their own right, would most likely prohibit their use in circuses, use of their furs and hunting them for fun. ${ }^{160}$ Yet, most importantly, such a recognition would most likely impact upon the permissibility of meat-eating: even if human beings desire to eat many animals, their interest in life and to be free from suffering would outweigh the right of most humans to kill them for food and, perhaps, only be permissible where this was necessary for a human being's survival. ${ }^{161}$ Given that our society is far from the point of being prepared to ban meat-eating generally, and the abuse of animals is pervasive, would the legal recognition of animals as persons not place the law on a collision course with human societal expectations?

It is important to recognise that law is evolutionary and the great social justice movements have taken time to achieve just laws. ${ }^{162}$ The fight for lesbian and gay equality, for instance, in South Africa began with the decriminalisation of sodomy: ${ }^{163}$ thereafter, various partnership rights were recognised by the courts ${ }^{164}$ and finally, after ten years (a very short period in fact), marriage rights were granted by the legislature ${ }^{165}$ after the intervention of the Constitutional Court. ${ }^{166}$ In my view, a similarly gradual process will be necessary in order to achieve the full recognition of animal rights. It is important therefore to articulate a conceptual framework through which such a gradual process can unfold. In my view, a critical notion in this area should be the concept of 'progressive realisation'. ${ }^{167}$ This concept was introduced in the context of socio-economic rights and is contained in the International Covenant

160 For an account of the widespread abuse of animal rights in South Africa, see M Pickover Animal Rights in South Africa (2005).

161 DeGrazia (note 48 above) 284-90.

162 The dismantling of apartheid took 45 years since its inception as a formal system in law in 1948 though of course the fight against segregation and racism took hundreds of years. See Lovvorn (note 148 above) who charts the course of the Civil Rights movement in the United States over more than a century and points to the implications for animal rights.

163 National Coalition for Gay and Lesbian Equality v Minister of Justice 1999 (1) SA 6 (CC).

164 These included immigration rights in National Coalition for Gay and Lesbian Equality $v$ Minister of Home Affairs (Home Affairs) 2000 (2) SA 1 (CC); pension rights in Satchwell v President of the Republic of South Africa 2002 (6) SA1 (CC); and joint adoption rights in Du Toit v Minister of Welfare and Population Development 2003(2) SA 198 (CC).

165 The Civil Union Act 17 of 2006.

166 Minister of Home Affairs $v$ Fourie; Lesbian and Gay Equality Project v Minister of Home Affairs 2006 (1) SA 524 (CC).

167 The 'progressive realization' of animal rights may differ in certain ways from 'progressive realization' in the context of socio-economic right. For instance, progressive realisation in the context of animal rights would mainly relate to widening the sphere of prohibitions on what may be inflicted upon other animals (human beings in many of these instances simply need to refrain from certain behaviours to respect animal rights). In the context of socio-economic rights, the concept generally relates to the gradual fulfilment of positive obligations to provide certain goods that cannot be provided immediately as a result of the lack of resources (or the like). Despite these differences, I still believe that the similarities discussed in the text highlight the usefulness of this concept in the context of animal rights. 
on Economic, Social and Cultural Rights as well as the South African Constitution. ${ }^{168}$ This notion recognises that the full realisation of these rights may not be possible at a particular point in time: yet, it nevertheless imposes an 'obligation to move as expeditiously and effectively as possible towards that goal'. ${ }^{169}$ It also requires that deliberately retrogressive measures generally not be taken and that they be carefully justified where necessary. ${ }^{170}$ This obligation is also related to a minimum core obligation to, at the very least, ensure the satisfaction of minimum essential levels of each right. ${ }^{171}$ Thus, it may not be possible to provide everyone with a decent house immediately but the government may nevertheless be obliged to ensure that individuals at least have shelter from the elements in the interim. ${ }^{172}$

In a similar vein, some of these principles could be applied in the context of realising animal rights. Whilst the full realisation of animal rights may not be possible in South Africa at present, nevertheless, a minimum core of rights could be developed to which each animal is entitled. ${ }^{173}$ Deliberately retrogressive measures should be banned and a progressive plan developed to extend the rights animals have over time. In addition, where the existing rights of animals (that are recognised in terms of this particular framework) may be limited or violated by a practice, a justification should be required that is able to pass the requirements of the limitation's clause in the South African Constitution. ${ }^{174}$ If such a justification is not forthcoming, the practice should not be allowed. Most importantly, this will require those wishing to violate animal rights, to show that the least restrictive means are being used in this regard.

In practice, progressive realisation of animal rights would mean that courts will, in all likelihood, not initially recognise the full implications of

168 See Art 2 of the International Covenant (note 65 above). It is also included in ss 26(2) and 27(2) of the South African Constitution.

169 General Comment 3 of the United Nations Committee on Economic, Social and Cultural Rights, $<$ http://www.unhchr.ch/tbs/doc.nsf/0/94bdbaf59b43a424c12563ed0052b664?Opendocument> para 9.

170 Ibid.

171 Ibid para 10

172 See D Bilchitz (note 134 above) 193-4.

173 This could involve initially something like the five freedoms developed by the UK Farm Animal Welfare Council: freedom from thirst and hunger, freedom from discomfort, freedom from pain, injury and disease, freedom to express normal behaviour, freedom from fear and distress. See http:// www.fawc.org.uk/freedoms.htm.

174 The Limitation Clause would allow for some flexibility in relation to animal rights: it would allow, for instance, courts to recognise that meat-eating is currently regarded as a legitimate purpose for limiting the rights of animals. On the other hand, not all abuses in the meat industry could be condoned simply on this basis and there would have to be an assessment concerning the relation between the limitation and the purpose as well as an evaluation as to whether the least restrictive means were used to achieve the purpose. In a ground-breaking case, the Israeli Supreme Court used principles of proportionality to stop the practice of force-feeding geese involved in the production of foie gras: see 'Noah'The Israel Association for the Protection of Animals v Attorney-General In the Supreme Court Acting as High Court of Justice, HCJ 9231/01 [2002-3]. The case is discussed in Mariann Sullivan \& David J Wolfson 'What's Good for the Goose ... The Israeli Supreme Court, Foie Gras, and the Future of Farmed Animals in the United States' (2007) 70 Law and Contemporary Problems 139. 
such rights by banning all forms of meat-eating. Yet, this does not mean, that the recognition of such rights would be meaningless: courts can require justification, for instance, as to whether the 'least restrictive means' are being used to rear animals for food. Much of the suffering imposed on animals in the process of rearing them for food is unnecessary. For instance, cattle are regularly castrated with no anaesthetics: such mutilation and violation of their basic rights to bodily integrity should not be accepted purely on grounds of commercial imperatives to speed up the castration process. Sows are kept in narrow metal-barred stalls that are barely bigger than the sow herself (known as a 'sow stall'): she is prevented from being able to exercise and is unable to turn around for nearly four months at a time. ${ }^{175}$ Laying hens are kept in battery cages that are so small they cannot stretch their wings, let alone walk or scratch the ground. ${ }^{176}$ These cages prevent most natural behaviours and lead to the degeneration of their bodies and deformities in their claws. ${ }^{177}$ About 4,700 million hens world-wide are kept in these conditions. ${ }^{178}$ In working towards the progressive elimination of animal exploitation, it is critical to end the worst forms of abuse. The European Union has already agreed to ban all cosmetic testing on animals from 2009, the sow stall by 2013 as well as banning the conventional battery cage by 2012 such that all production will use free-range methods. ${ }^{179}$ If South African law required that these measures be imposed on industries using animals, a large number of animal lives will be improved without majorly impacting upon the lifestyles and well-being of humans in South Africa. The initial stage of protecting animal interests should thus involve banning of worst forms of abuse and improving the welfare of animals in these conditions. This stage could also involve educational measures that are designed to sensitise human beings to the lives of animals. Over time, more wider-ranging measures could be introduced that would lead to the goal of a truly just society in which animals are not exploited and respected for the kinds of beings that they are.

The first step, however, is to recognise the arbitrariness and unjustifiability of the current legal framework relating to animals. It is to place animals on the legal map: that has been the purpose of this article. In describing the transformative vision of the Constitution, Justice Mohamed states that it represents a

decisive break from, and a ringing rejection of, that part of the past which is disgracefully racist, authoritarian, insular, and repressive, and a vigorous identification of and commitment to a democratic, universalistic, caring and aspirationally egalitarian ethos expressly articulated in the Constitution. ${ }^{180}$

This ethos embodied in the Constitution is currently at odds with the arbitrary focus on the human alone and the failure currently to recognise the rights of

175 See C Druce \& P Lymbery 'Outlawed in Europe' in P Singer (ed) In Defense of Animals 124.

176 Ibid 128 .

177 Ibid 129.

178 Ibid.

179 Ibid 126 and 130. On the ban on testing cosmetics on animals, see <http://www.cosmeticsdesigneurope.com/Products-Markets/EU-refuses-bid-to-lift-ban-on-animal-cosmetics-testing>.

$180 S v$ Makwanyane (note 3 above) para 262. 
other animals. I have sought to demonstrate in this article that recognising the worth and rights of animals is simply a logical consequence of being committed to human rights in that any such commitment must seek to protect all those who are similarly situated and whose interests matter. South African society can only truly be transformed where treatment of individuals does not take place on the basis of arbitrary distinctions or powerful interests. A recognition of the capabilities of animals means that we are forced to consider them as individuals, as having dignity and this in turn requires us to consider the impact upon their interests of every decision we make. The law must be transformed to ensure that it embodies this recognition: I have argued that animals should be recognised as legal persons and proposed various possibilities for giving effect to such a change in classification. This is not something impossible for the legislature or the courts to achieve. Indeed, in a recent case in India dealing with the maltreatment of circus animals, a court made a number of wide-ranging findings that could transform the status of animals were they adopted in our law. The Court stated that

though not homo sapiens, they are also beings entitled to dignified existence and humane treatment sans cruelty and torture ... Therefore, it is not only our fundamental duty to show compassion to our animal friends, but also to recognise and protect their rights ... If humans are entitled to fundamental rights, why not animals? 